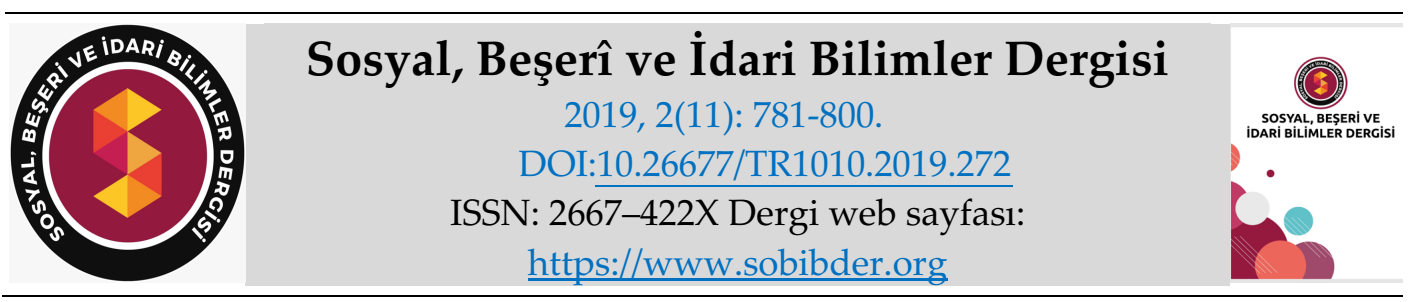

ARASTTIRMA MAKALESI

\title{
Döviz Kurlarının Ticari Dışa Açıklık Üzerindeki Etkisi: BRICS-T Ülkeleri Üzerine Bir Panel ARDL Analizi
}

Dr. Öğr. Üyesi Mehmet Metin DAM, Adnan Menderes Üniversitesi, Nazilli İ̈BF, Aydın, e-posta metindam@hotmail.com

ORCID: https://orcid.org/0000-0003-3980-7832

Arş. Gör. Orhan ŞANLI, Adnan Menderes Üniversitesi, Nazilli İ̈BF, Aydın, e-posta: orhan.sanli@adu.edu.tr

ORCID: https://orcid.org/0000-0002-3366-8993

Öz

Birçok uluslararası değerlendirmeye göre dünyanın yükselen ekonomileri olarak gösterilen BRICS ülkelerine (Brezilya, Rusya, Hindistan, Çin ve Güney Afrika) Türkiye de eklenerek BRICST grubu oluşturulmuştur. Bu grubun 2000'li yıllardan sonra dünya ticaretinde ve ekonomisinde önemi gittikçe artmaya başlamıştır. Bu bağlamda, döviz kurları ile dış ticaret arasındaki ilişki BRICS-T ülkeleri için her geçen gün önem arz etmeye başlamıştır. Bu çalışmada, döviz kurlarının ticari dışa açıklık üzerine etkisi, BRICS-T ülkeleri için 1996-2017 dönemi yıllık veriler kullanılarak panel ARDL yöntemiyle analiz edilmiştir. Serilerin durağanlığı ADF ve PP panel birim kök testleriyle, nedensellik ilişkisi Dumitrescu ve Hurlin (2012) testiyle, eşbütünleşme ilişkisi panel ARDL-PMG yaklaşımıyla tahmin edilmiştir. Çalışmanın sonucunda, döviz kurundan ticari dişa açılığa doğru ve döviz kurundan enflasyona doğru tek yönlü bir nedensellik ilişkisi varken, enflasyondan ticari dışa açılığa doğru çift yönlü bir nedensellik ilişkisi tespit edilmiştir. Ayrıca uzun dönemde, enflasyondaki \%1'lik artışın ticari dışa açıklığ $\% 1,26$ oranında arttırdığı gözlemlenmiştir.

Anahtar Kelimeler: Ticari Dışa Açılık, Döviz Kurları, Panel ARDL, BRICS-T Ülkeleri.

Makale Gönderme Tarihi: 09.07.2019

Makale Kabul Tarihi: 05.11.2019

\section{Önerilen Atıf:}

Dam, M.M. ve Şanlı, O. (2019). Döviz Kurlarının Ticari Dışa Açıklık Üzerindeki Etkisi: BRICS-T Ülkeleri Üzerine Bir Panel ARDL Analizi, Sosyal, Beşeri ve İdari Bilimler Dergisi, 2(11): 781-800.

(c) 2019 Sosyal, Beşerî ve İdari Bilimler Dergisi. 


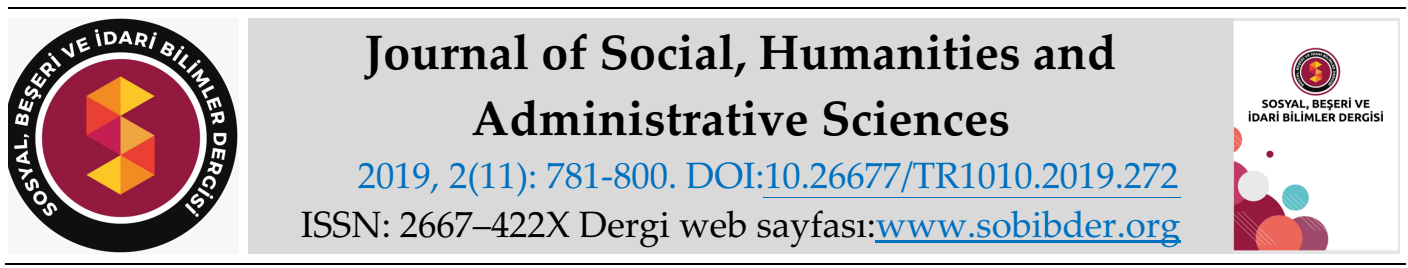

RESEARCH PAPER

\title{
The Effect of Foreign Exchange Rates on Commercial Openness: A Panel ARDL Analysis on BRICS-T Countries
}

Assist. Prof. Dr. Mehmet Metin DAM, Adnan Menderes University, Nazilli Faculty of Economics and Administrative Sciences, Aydın, e-mail: metindam@hotmail.com

ORCID: https://orcid.org/0000-0003-3980-7832

Res. Assist. Orhan ŞANLI, Adnan Menderes University, Nazilli Faculty of Economics and Administrative Sciences, Aydın, e-mail: orhan.sanli@adu.edu.tr

ORCID: https://orcid.org/0000-0002-3366-8993

\begin{abstract}
According to many international evaluations, as shown in the world's emerging economies BRICS-T was formed by adding Turkey to BRICS (Brazil, Russia, India, China and South Africa), the world's emerging countries. The importance of this group in the world trade and economy started to increase after 2000s. In this context, the relationship between exchange rates and foreign trade has become increasingly important for BRICS-T countries. In this study, the effect of exchange rates on trade openness was analysed by using panel ARDL method for BRICS-T countries using annual data for 1996-2017 period. Stability of the series was estimated by ADF and PP panel unit root tests, causality relationship was evaluated by Dumitrescu and Hurlin (2012) test, and cointegration relationship was estimated by panel ARDL-PMG approach. As a result of the study, while there is a one-way causality relationship from exchange rate to trade openness and from exchange rate to inflation, a two-way causality relationship from inflation to trade openness has been determined. In addition, in the long run, the 1\% increase in inflation increased the trade openness by $1.26 \%$.
\end{abstract}

Keywords: Trade Openness, Exchange Rates, Panel ARDL, BRICS-T Countries.

Received: 09.07.2019

Accepted: 05.11.2019

\section{Suggested Citation:}

Dam, M.M. and Şanl1, O. (2019). The Effect of Foreign Exchange Rates on Commercial Openness: A Panel ARDL Analysis on BRICS-T Countries, Journal of Social, Humanities and Administrative Sciences, 2(11): 781-800.

(c) 2019 Sosyal, Beşerî ve İdari Bilimler Dergisi. 


\section{Gíriş}

Küreselleşmeyle birlikte ülkeler arası iletişim ve ülkelerin birbirlerinden etkilenme dereceleri giderek artmaya başlamıştır. Örneğin, bir ülkede meydana gelen ekonomik sorunlar, o ülkeyle ticaret yapan diğer ülkeleri de etkilemektedir. Bu bağlamda en iyi örneklerden biri ABD'de başlayıp dünyaya yayılan 2008 Mortgage Krizi'dir. Dolayısıyla bir ülkede ortaya çıkn krizler, diğer ülkelerin ticaret ve döviz kurlarını etkilemektedir (Yücesan vd., 2017: 1289-1290). 2008 Küresel Krizi'nden sonra, ABD Merkez Bankası kademeli olarak faiz arttırma politikaları uygulamaya başlamıştır. Bu durum daha önce doğuya kaptırılan ticaretin ve sermayenin tekrar batıya taşınması anlamına gelmektedir. Dünya genelinde ABD'nin başlattığı ticari savaşlar gelişmekte olan ülkelerde döviz kurlarının yükselmesine neden olmaktadır. Döviz kurlarının yükselmesi, özellikle Türkiye gibi ithalatı yüksek ülkelerde ekonomik sorunlara yol açmaktadır. Artan kurlar, bir yandan ithalatı pahalı hale getirirken diğer yandan ülke içinde enflasyonu tetiklemektedir. 2008'den sonra, FED'in (Amerika Birleşik Devletleri'nin merkez bankası) faiz arttırmaya başladığı dönemle beraber, BRICS-T ülkelerinde kurlar artmaya başladı. Çin, Rusya gibi ülkelerde ihracatın yüksek olmasından dolayı, şimdiye kadar bu ülkelerde kurlar ihracat üzerinde önemli düzeyde bir probleme yol açmadı. Ancak Brezilya ve Türkiye gibi cari açığın yüksek olduğu ülkelerde; döviz kurları, fiyatlar genel seviyesi, faiz oranları, işsizlik ve ekonomik büyüme gibi temel makroekonomik göstergeler negatif olarak etkilemektedir. İthalatın pahalı hale gelmesi ihraç ürünlerinin de göreceli uluslararası piyasada daha maliyetli hale gelmesine neden olmaktadır. Bu durum ise ihracatı olumsuz yönde etkilemektedir.

2017 yılı itibariyle, ABD başkanı Donal Trump'ın korumacı politikalarıla tekrar hız kazanan ticaret savaşları, Çin ve Rusya gibi ülkeleri de olumsuz yönde etkilemeye başlamıştır. ABD'nin demir ve çelik ürünlerinin ithalatına ek vergi koyması, ABD'nin Çin, Rusya ve İran gibi ülkelerle siyasi gerilim yaşaması, dünya genelinde gelişmekte olan ülkelerdeki kurların yükselmesine neden olmaktadır. ABD'nin başlattığı bu savaşlar neticesinde yeni korumacılık önlemleri tekrar gündeme gelmeye başladı. Çünkü 2008 'den sonra gelişmiş ülkeler artık dişa açılma stratejiler yerine içe dönmeye odaklı politikalar uygulamaya başladılar (Çetinkaya vd., 2018: 710-711).

Bu çalışmada BRICS-T ülkelerinde döviz kurlarının ticari dışa açıklık üzerindeki etkisi panel ARDL yöntemiyle analiz edilmiştir. Çalışmanın birinci bölümünde; BRICS-T ülkelerinde, diş ticaret, döviz kurları ve makroekonomik değişkenler hakkında genel bilgi verilmiştir. İkinci bölümde; ticari dışa açıklık ve döviz kuru arasındaki ilişkiyi inceleyen literatür taraması sunulmuştur. Üçüncü bölümde; çalışmanın ampirik analiz ve bulgulara yer verilmiş, son kısımda ise sonuç ve değerlendirme ile çalışma sonlandırılmıştır.

\section{BRICS-T ÜLKELERİ VE 2000 SONRASI MAKROEKONOMİK GÖSTERGELER}

İkinci Dünya Savaşı'ndan sonra uluslararası ilişkileri yönlendiren dengesiz güç dağılımı, son zamanlarda hızla değişmeye başladı. Yakın zamana kadar küresel yönetim batı ülkelerinin kontrolündeki IMF, WB, UN gibi uluslararası kurumlar tarafından idare ediliyordu. ABD ve $\mathrm{AB}^{\prime}$ nin liderliğini sürdürdüğü bu dönem boyunca, Asya, Latin Amerika ve Afrika bölgeleri küresel liderliğin dışında tutuldular. Fakat 2008 Küresel Krizi, gelişmiş batı ülkeleri tarafından iyi yönetilemedi ve kriz birçok gelişmiş ülkeyi olumsuz yönde etkiledi. Bu durum gelişmekte olan ülkelerin, özellikle yükselen ekonomilerin önemini arttırdı. Kısacası, batı ülkeleri özellikle gelişmekte olan ülkelerin başında gelen BRICS ülkeleri ile işbirliği yapmaya mecbur kaldı (Onyekwena vd., 2014: 6-7). Yükselen ekonomileri 2001 yılında bir araya getirip BRIC kavramını ilk olarak ortaya atan kişi Goldman Sachs yönetim kurulu başkanı Jim O'Neill'dir. Jim, “Building Better Global Economic BRICS" adlı çalışmasında, geleceğin ekonomilerini sınıflandırırken, bu 
ülkelerin yeni yüzyılda yeni fırsatlar ve yeni imkanlarla dolu olacağını, 2050'li yıllarda dünyanın en büyük küresel güçleri olacağını belirtmiştir (Lemco, 2016: 2). Dünya küresel liderliği, politik, ekonomik ve askerî açıdan değişmeye başladı. Özellikle Çin'in dünya dış ticaretinde en büyük paya sahip ülke haline gelmesi, sermayenin yükselen ekonomilere kayması, güney kuzey diyaloğunun artması bu durumun en iyi göstergeleridir. Fakat bu değişime engel olmak isteyen başta ABD olmak üzere gelişmiş ülkeler ticaret ve kur savaşlarını tekrar gündeme getirmeye başladılar.

2000 sonrası dönemdeki son 10 yılda, gelişmekte olan ülkelerin ekonomilerindeki büyüme performansları dikkat çekmektedir. Artan bu hızlı büyüme sayesinde gelişmekte olan ülkelerin dünya gayrisafi yurt içi hasılasında (GSYH), dünya ticaretinde, toplam doğrudan yabancı yatırımlarda ve uluslararası finansal piyasalardaki payları artmaya başlamıştır. Özellikle 2008 Krizi sonrası ortaya çıkan bu yeni durum küresel dengelerin değişmesine, G-8'den çok G-20'nin gündeme gelmesine neden olmuştur (Shaygani vd., 2015: 564-565). Küresel güçlerin değişmeye başladığı bu dönemde, yükselen ekonomilerin başında Brezilya, Rusya, Hindistan, Çin, Güney Afrika ve bu gruba son zamanlarda bazı çalışmalarda dahil edilen Türkiye yer almaktadır. BRICS ülkelerinin dünya ekonomisinde artan payları, yüksek beşerî sermayeye ve oldukça geniş doğal kaynaklara sahip olmaları, yüksek büyüme performansları ve sahip olunan yüksek genç nüfus sayesinde gelecek 20-30 yıl içerisinde dünya ekonomisinde büyük rol oynayan ülkeler olacağ 1 beklenmektedir (Rodionova ve Apifantseva, 2017: 107-110). 2000 yılı itibariyle dünya ithalatı ve ihracatında payları artmaya başlayan BRIC ülkeleri, ilk defa 2006 yılında bir araya gelerek BRIC ülkeleri olarak anılmaya başlanmıştır. 2010 yılında bu gruba Güney Afrika da dahil olmuştur. BRIC ülkeleri özellikle güney bölgeleri ile kurdukları ekonomik ve ticari ilişkilerde ekonomikfinansal yardım, işbirliği ve stratejik desteklere dayanan yeni bir uluslararası kalkınma politikasını gündeme getirdiler. Ortaya çıan yeni dengeler, dünya ticaretinin ve kalkınma stratejilerinin yer değiştirmesine neden oldu. Türkiye, Suudi Arabistan, Endonezya gibi ülkelerin büyüme performansları ile beraber gelişmiş ülkelerin bu ülkelerle işbirliği ve diyaloğu artmaya başlamıştır (European Parliament, 2012). BRICS ülkeleri dünya genelinde ticaret yaparken aynı zamanda düşük gelirli ülkelerle de daha yakın ilişkiler kurmaya başladılar. Böylece, KuzeyKuzey ittifakı ile ilişkileri olan fakat dünyada yeni bir işbirliğine dayanan Güney-Güney ittifakının oluşmasına zemin hazırladılar (Yamoussoukro, 2008). BRICS ülkelerinin diğer gelişmekte olan ülkelerle dengeli ve güçlü bir bağları vardır. Yüksek performans ve hızla büyümelerini devam ettirmeleri halinde, yükselen ekonomilerin başında yer alan Brezilya, Rusya, Hindistan ve Çin 2050 yılı ortalarında dünya ekonomisinin en önemli temsilcileri olmaları beklenmektedir. Gelişmekte olan ülkeler ve dünya ekonomisi için hayati öneme sahip olan BRICS ile işbirliğinin önemi üç temel nedene dayanmaktadır (O'Neill, 2001: 3-7)

$\checkmark$ Ekonomilerinin olağan üstü büyüklüğü

$\checkmark$ Dünya ekonomisinde önemi artan güçlü büyüme oranları

$\checkmark$ Güçlü bir politik söyleme sahip olma isteği

Goldman Sach-O'Neill, BRICS ülkelerini sınıflandırırken aynı zamanda Türkiye'nin de dahil olduğu MINT kavramını kullanmaya başlamıştır. Meksika, Endonezya, Nijerya ve Türkiye birbirlerine benzer ekonomileri ve demografik yapılarıyla, BRICS ülkeleri gibi gelecek 50 yıl içerisinde dünyanın en büyük 15 ekonomisi içerisinde yer alacakları yönünde projeksiyonlar yapılmaktadır (Kokotović ve Kurečić, 2016: 21-23). Çin'in başını çektiği BRICS-T ülkeleri, Güney Afrika yerine Endonezya ve Meksika'nın dahil olduğu E-7 adında yeni bir grubu ortaya çıkarmıştır. Öyle ki sahip olunan genç nüfus, aktif iş gücünün ve tüketim oranlarının yüksekliği, büyüme ve kalkınma konusunda doyum noktasından uzak olmaları gibi nedenlerden dolayı G7'nin yanı sıra E-7'nin de gündeme gelmesine neden olmuştur. 1993 yılında satın alma gücü paritesine göre dünya gayrisafi yurt içi hasılasının $\% 42$ 'sini temsil eden yükselen ekonomiler, 
2017 itibariyle bu oranı \%59'a kadar çıkarmayı başarmışlardır. 1993 yılında, dünya GSYH'sinin \%46'sına sahip olan G-7 ülkelerinde 2017 yılında bu oran \%31'e kadar gerilemiştir. Şekil 1'de görüldüğü gibi satın alma gücü paritesi bakımından 2014 yılında E-7 ülkeleri G-7 ülkelerini geride bırakmıştır (Bergevin, 2018).

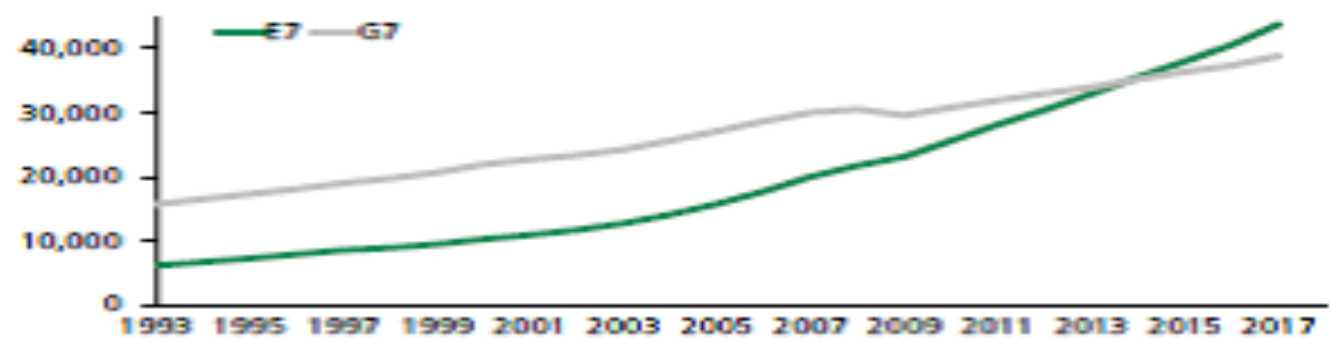

Şekil 1: Satın Alma Gücü Paritesine Göre Reel GSYH(Dolar)

Kaynak: Bergevin, 2018.

Yüksek kurlar, dış ticaret fazlası veren ülkelerde büyük avantaj sağlarken, cari açık veren ülkelerde büyük fırsat kayıplarına yol açmaktadır. Dünya ticaretinin en büyük kısmı dolar ve ardından Euro ile yapıldığı düşünüldüğünde, dünya ekonomisinden aldıkları payları arttırmaya çalışan yükselen ekonomilerin kurlarla mücadele politikaları büyük önem arz etmektedir.

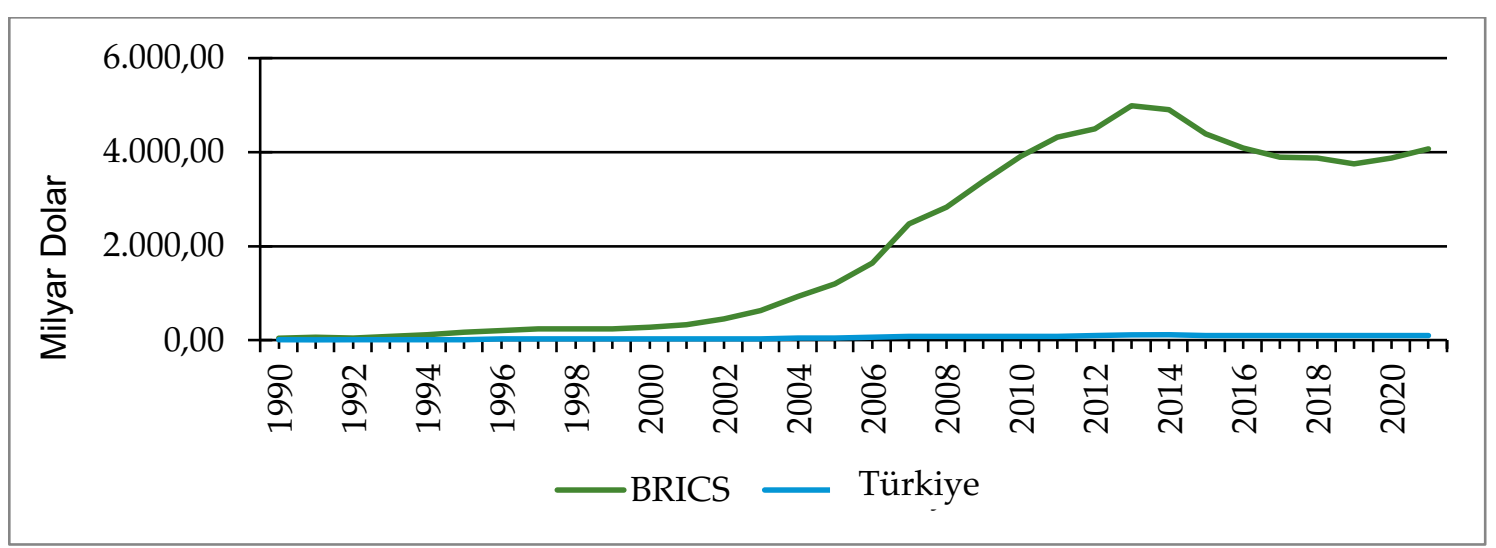

Şekil 2: BRICS ve Türkiye'de Toplam Döviz Rezervlerindeki Değişim

Kaynak: Islamıc Development Bank-Data Indicator ve OECD'den elde edilen verilerle şekil yazarlar tarafından oluşturulmuştur.

BRICS ülkelerinin en önemli özelliklerinden biri de özellikle Çin'in lider olduğu yüksek döviz rezervlerine sahip olmalarıdır. Şekil 2'de görüldüğü gibi BRICS ve Türkiye'de döviz rezervleri bir artış eğilimindedir. 1995 yılına kadar 160 milyar dolarlık rezerve sahip BRICS ülkeleri, 2000'li yıllardan sonra büyük bir hızla rezervlerini arttırmayı başarmışlardır. 20 yıllık dönem sonrası 2013 yılında yaklaşık 4.986 milyar dolarlık rezerve ulaşabilmişlerdir. Türkiye ise 1994 yılında 7 milyar dolar olan döviz rezervini BRICS ülkelerinin en yüksek seviyeye ulaştığı 2013 yılında en üst seviyeye taşıyarak 110 milyar dolara kadar çıarabilmiştir. 2018 yılında ise BRICS-T ülkelerinde döviz rezervleri azalarak toplamda 4.700 milyar dolar olarak gerçekleşmiştir. Çin'in tek başına dünya döviz rezervinin yaklaşı \%30'una sahip olmasıyla dünyada lider konumdadır. Dünya sıralamasında en fazla döviz rezervine sahip ülkeler sıralamasında ilk 10'da Brezilya, Rusya, Hindistan ve Çin yer almaktadır. Döviz rezervlerinin bu kadar bol olması bu ülkelerde küresel savaş ve krizlere karşı büyük bir güç olarak algılanmaktadır. Döviz rezervlerinin yüksek 
olması, gelişmekte olan ülkelerde ekonomik büyümeyi pozitif yönde etkilemektedir. Ayrıca rezervler, küresel piyasada doların tekel gücüne karşı bir koruma aracı olarak kullanılır. İç piyasada döviz rezervleri özel sektör, merkez bankaları ve kamu kesiminde ekonomik dengelenmeye olumlu katkı sağlar (Luna, 2016: 5-6). BRIC-T ülkelerinde özellikle 2000 sonrası döviz rezervlerinin hızlı yükselmesinde bu ülkelerin küresel yatırım merkezleri haline gelmeleri etkili olmuştur. Çin ve Hindistan'ın sahip olduğu genç ve ucuz işgücü nüfusu, doğal kaynakların bolluğu, faiz oranlarının ve enflasyonun batılı ülkelere nazaran yüksek olması, kalkınma politikalarını harekete geçirmede başarılı olmaları gibi nedenlerden dolayı, bu ülkeler dünya yatırım ve sermayesinin önemli bir kısmını kendi ülkelerine çekmeyi başarabilmişlerdir.

Şekil 3'te BRICS-T ülkelerinde cari denge değerleri mevcuttur. BRICS ülkelerinde cari denge fazla verirken Türkiye'de 2002 sonrası cari denge sürekli negatif olmuştur. BRICS ülkelerinin dünya piyasasına çıkmaya başladığı 2000'li yıllar itibariyle cari işlemler sürekli artı değer almıştır. Bu duruma sebep olan ülke Çin'dir. 2008 yılında 448 milyar dolar cari fazla varken 2018 yılında 154 milyar dolara kadar gerilemiştir. Fakat 2020 yılına doğru BRICS ülkelerinde cari açık dengesi sıfıra doğru yaklaşacağı tahmin edilmektedir. Türkiye, her ne kadar hızlı büyüme potansiyeline sahip olsa da cari işlemler açığı genel olarak artma eğilimindedir. 2018 yılında bu açık 40 milyar dolara yakın bir değer almıştır. Türkiye' de bu sorunun nedenleri arasında üretimin ve ihracatın ithalatı karşılamaya yetmemesi vardır. Ayrıca 2018 itibariyle yüksek faizler ve artan kur baskıları nedeniyle ithalatın yavaşlamaya başlaması cari işlemlerde kısmen bir dengelemeye neden olmuştur.

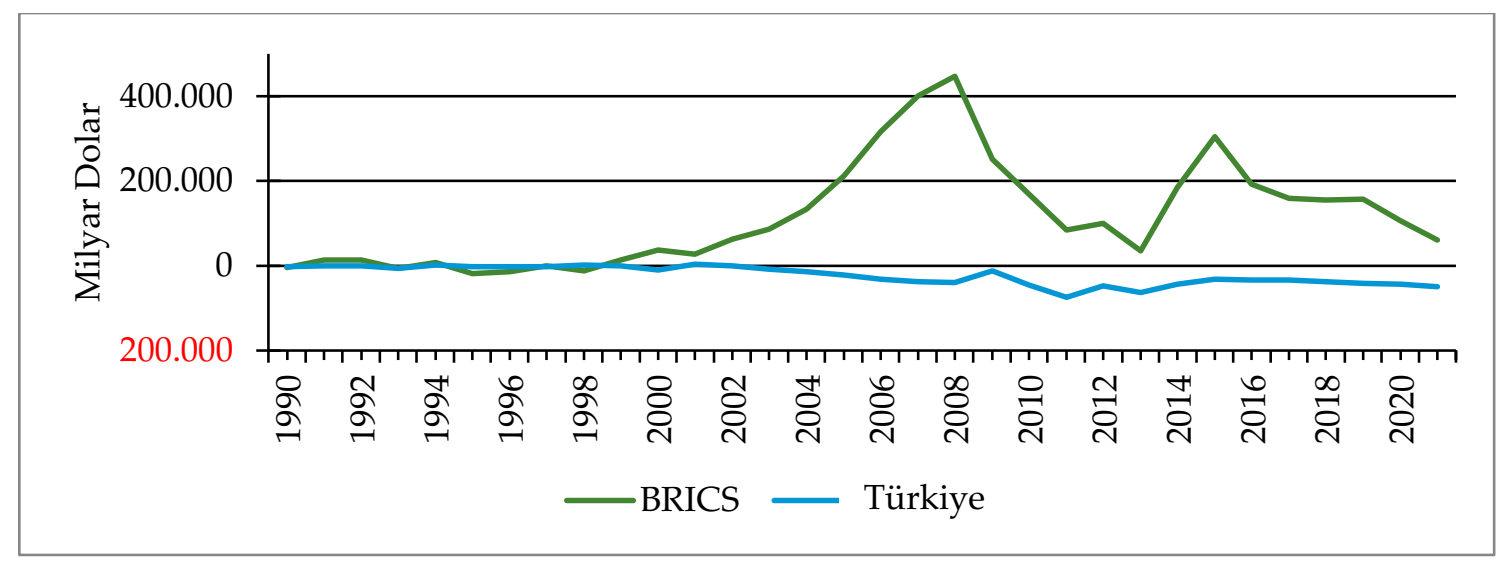

Şekil 3: BRICT-T Ülkelerinde 1990-2020 Arası Cari İşlemler Dengesi (Milyar Dolar)

Kaynak: Islamic Development Bank-Data Indicator ve OECD'den elde edilen verilerle şekil yazarlar tarafından oluşturulmuştur.

BRICS ülkelerinde cari işlemler dengesi dalgalı bir seyir izlemiştir. Bu ülkelere dışarıdan gelen sermayenin fazlalığı ve üretim neticesinden ihracatın da bir hayli yüksek olması dış ticarete olumlu katkı yaptığı ortadadır. Fakat son yıllarda ABD-Çin eksenli ticaret ve kur savaşları BRICS ülkelerinin ekonomilerini ve diş ticaret değerlerini etkilemektedir. ABD Merkez Bankası'nın faiz arttırma politikalarının devam etmesi, ABD'nin ticaret savaşlarını yeniden alevlendirmesi Türkiye' de dahil yükselen ekonomilerde kurların artışına neden olmuştur. Yüksek kurlar bir süre ihracatı desteklese de uzun dönemde BRICS-T ülkelerinin ekonomik ve diş ticaret performanslarına zarar vereceği düşünülmektedir. 


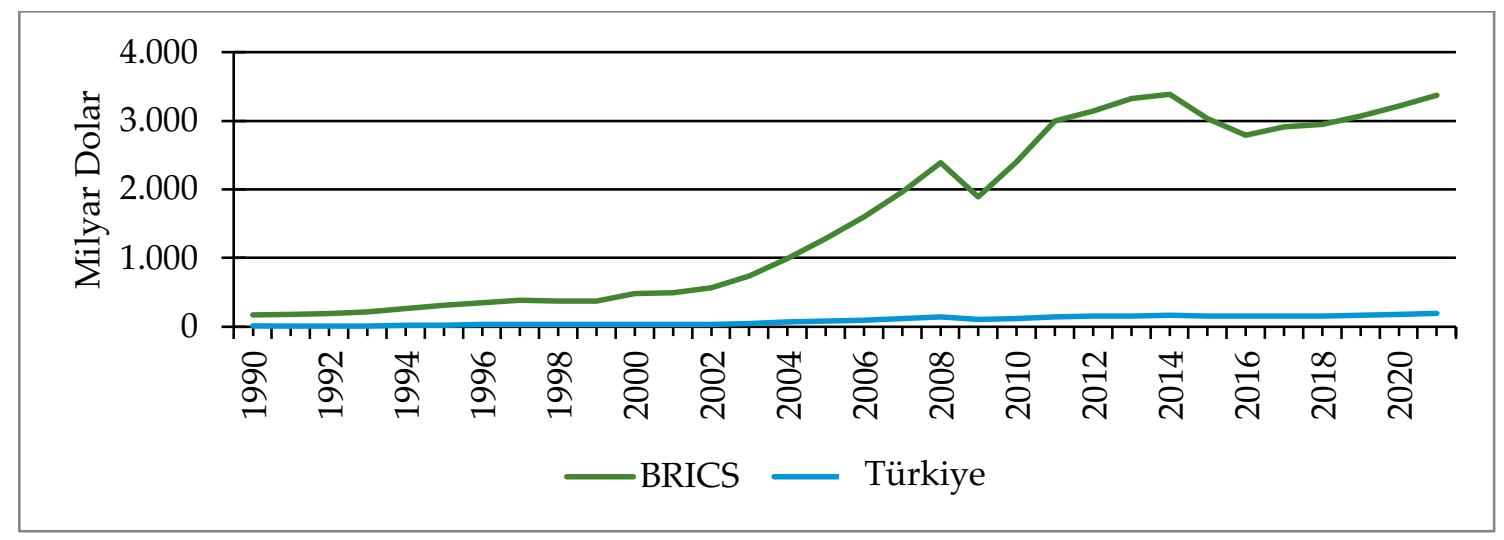

Şekil 4: BRICS-T ülkelerinde 1990-2020 Arası Mal İhracatı (Milyar Dolar)

Kaynak: Islamıc Development Bank-Data Indicator ve OECD'den elde edilen verilerle şekil yazarlar tarafından oluşturulmuştur.

BRICS ülkelerinde mal ihracatı 2008 yılına kadar sürekli artmıştır. 2009 yılında krizin etkisiyle azalan ihracat, 2014 yılına kadar tekrar artmaya başlamıştır. 2014 yılında BRICS ülkelerinde ihracat değeri 3.338 milyar dolara kadar yükselmiştir. Bu rakamlar içinde en büyük pay yine dünyanın en fazla ihracatını yapan Çin'e aittir. Türkiye'de ise 2001 krizinden sonra kayda değer artışlar görülmeye başlandı. 2008 krizin etkisiyle azalan ihracat değeri 2018 itibariyle 155 milyar dolara kadar yükselmiştir.

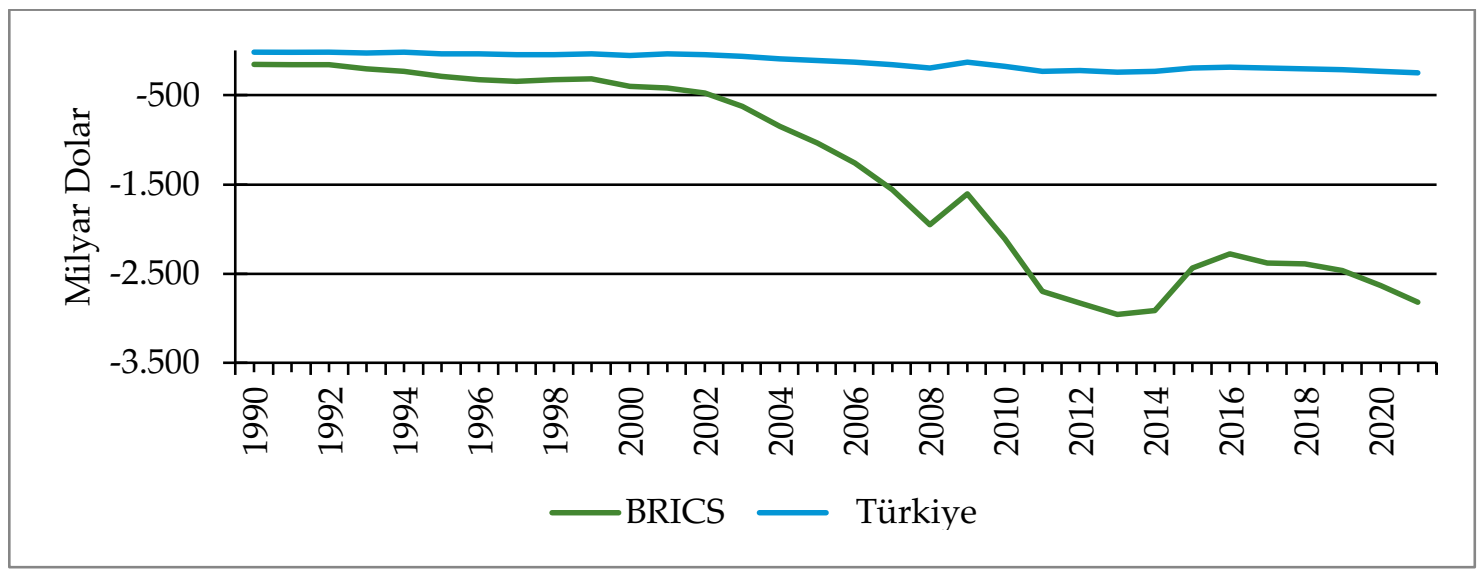

Şekil 5: BRICS-T Ülkelerinde 1990-2020 Arası Mal İthalatı (Milyar Dolar)

Kaynak: Islamıc Development Bank-Data Indicator ve OECD'den elde edilen verilerle şekil yazarlar tarafından oluşturulmuştur.

Dünya ekonomisinde damga vurmaya devam eden BRICS ülkelerinde mal ithalatı genel olarak artma eğilimindedir. 2000'li yıllar itibariyle ekonomik performansları yükselmeye başlayan bu ülkelerde ithalat değerleri de önemli derecede artmaya başlamıştır. İthalatın en fazla olduğu yıl 2013 yılıdır. Aynı yılda Türkiye'nin ithalatı da en yüksek seviyeye ulaşarak yaklaşık 241 milyar dolar olarak gerçekleşmiştir. 


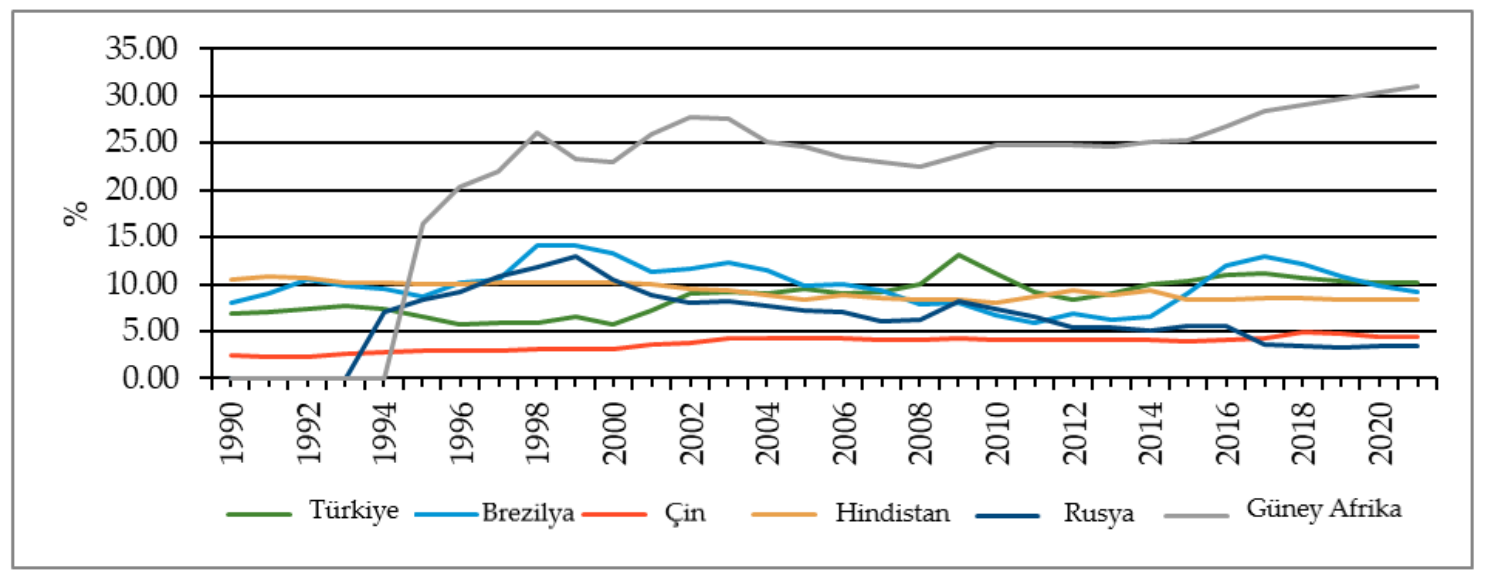

Şekil 6: BRICS-T Ülkelerinde 1990-2020 Arası İşsizlik Oranları (\%)

Kaynak: Islamic Development Bank- Data Indicator ve OECD'den elde edilen verilerle şekil yazarlar tarafından oluşturulmuştur.

2000 yılı itibariyle BRICS-T ülkelerinde işsizlik oranlarının en yüksek olduğu ülke Güney Afrika'dır. Ortalama \%25'lere ulaşan işsizlik oranları Güney Afrika'da armaya devam etmektedir. İşsizlik oranlarını son 20 yılda genel olarak sürekli azaltmayı başaran Rusya'da işsizlik oranı, 2017 itibariyle Çin'in işsizlik oranlarının altına düşmeye başlayarak 2018 yılında Rusya' da \%3,5 olarak gerçekleşmiştir. Çin, 2017'ye kadar işsizlik oranlarında genel olarak artış yaşasa da BRICS-T ülkelerinde işsizliğin en düşük olduğu ülke olmuştur. Rusya, Çin ve Hindistan'da işsizlik oranları \%10'un altında yer almaktadır. Fakat Brezilya ve Türkiye' de işsizlik oranları 2015 sonu itibariyle \%10'un üzerine çıkmıştır. Bu iki ülkede yerli paranın dolar karşısında değer kaybetmeye başladığı 2013 itibariyle işsizlik oranları da artma eğilimine girmiştir.

Şekil 7, BRICS-T ülkelerinde dış ticaretin GSYH içindeki payını göstermektedir. 2000'li yıllardan önce Hindistan ve Brezilya' da toplam dış ticaretin GSYH içindeki payı \%20'nin altında kalmıştır. Fakat bu dönemde sonra Hindistan'ın GSYH içindeki dış ticaretin payı hızla artmaya başlamıştır. Genel olarak bütün dönemlerde dış ticaretin GSYH içindeki payının en yüksek olduğu ülke Güney Afrika olmuştur. Ortalama Güney Afrika'da bu oran \%60'ın üzerindedir. 2000'li yılların öncesinde en yüksek oran Rusya'ya aitti. Fakat 2000 sonrası Türkiye, Güney Afrika ve Çin'in dış ticaretlerinin GSYH içindeki payı Rusya'yı geçmiş gözükmektedir. Çin'de, 2010 yılına kadar dış ticaretin GSYH içindeki payı sürekli artarken, bu tarihten sonra küresel ekonomik savaşların hız kazanması nedeniyle giderek azalmaya başlamıştır. Türkiye, bu grup içerisinde Güney Afrika'dan sonra dış ticaretin GSYH içindeki payını en düzenli şekilde arttıran ikinci ülkedir. 2017-2018 yıllarında, Türkiye'de meydana gelen kur şokları GSYH'nin azalmasına yol açmıştır. Ayrıca ihracatın artış eğilimine girmesi, toplam dış ticaretin GSYH içindeki payının artmasına neden olmuştur. 


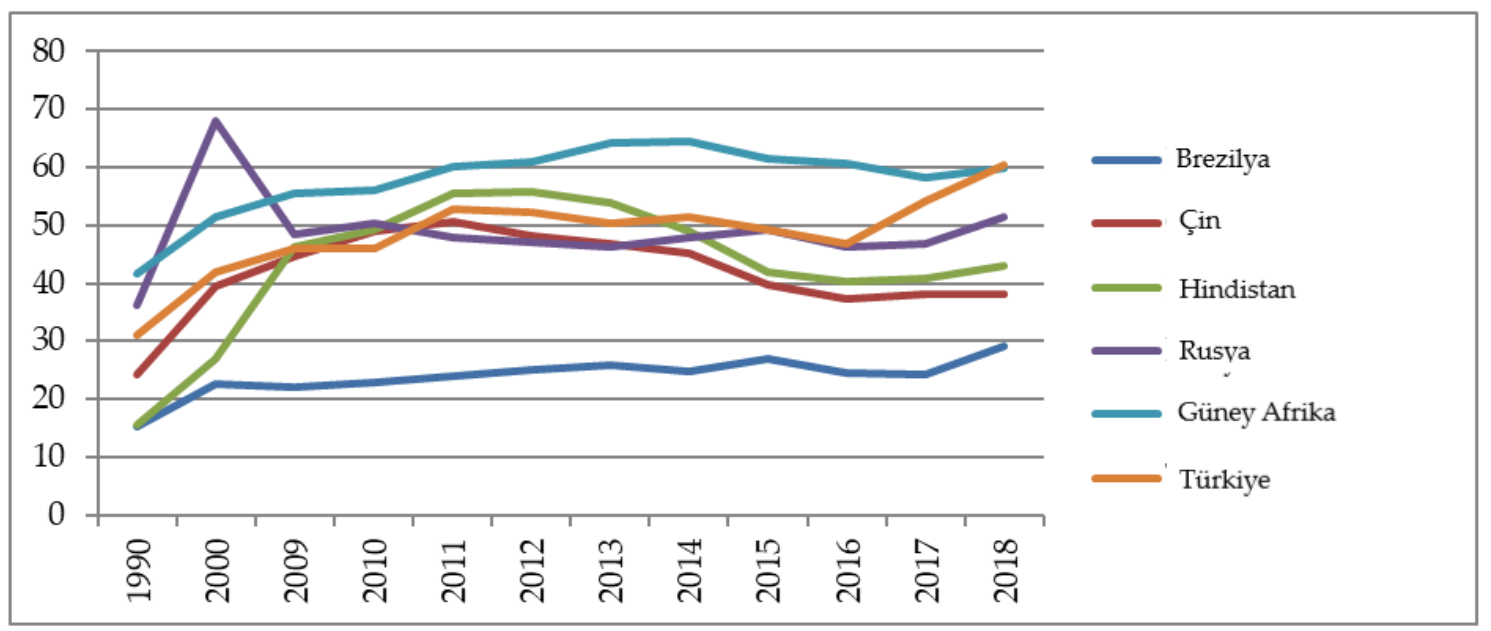

Şekil 7: BRICS-T Ülkelerinde Dış Ticaretin GSYH İçindeki Payı

Kaynak: Dünya Bankasından elden edilen verilerle tablo yazarlar tarafından oluşturulmuştur.

BRICS ülkeleri ile Türkiye karşılaştırıldığında özellikle Çin ve Hindistan'ın son yıllarda göstermiş olduğu ticari performans Türkiye'den daha iyi bir durumdadır. Dünya ekonomisine 1990'lı yıllardan sonra BRICS ülkeleri ve Türkiye'nin katkıları hız kazanmış, 2000'li yıllar da bu hız maksimum seviyeye çıkmıştır. Bu ülkelerin GSYH değerleri, dış ticaret rakamları, döviz rezervleri, 2010 yılı sonrasında gelişmiş ülkeleri geçerek küresel ekonomide kur ve ticaret savaşlarına neden olmuştur. ABD ile Çin arasında 2018 yılında başlayan ticaret savaşları Çin'in yukarıdaki grafiklerde ifade edildiği gibi yüksek ticari ve ekonomik performanslarının önüne geçmek amacıyla başlamıştır. 2020 yılına girilirken süreç, küresel ekonomiyi de etkileyen bir şekilde devam etmektedir. BRICS grubunun yükselen ekonomileri, gelecek 30 yıl içerisinde G7'nin değişeceği yönünde belirtiler göstermektedir.

\section{LITERATÜR TARAMASI}

Döviz kurlarının dış ticaret üzerindeki etkisini araştıran çalışmalar dünya genelinde oldukça fazladır. Özellikle yükselen ekonomilerin dolar karşısında yerel paralarının aldığ 1 değer bu ülkelerde dış ticareti önemli derecede etkileyen unsurların başında gelmektedir.

Kharrobi, 2011 yılında yaptığı reel döviz kurları ve ticaret dengesini konu alan çalışmasında 20 OECD ülkeleri üzerinde panel nedensellik testi yapmıştır. Bu sonuçlara göre reel döviz kurundaki değişmeler ABD dış ticaret açı̆̆ını kapatırken, Çin'in sahip olduğu ticaret fazlası değerlerini azaltmaktadır.

Bostan vd., 2018 yılında Romanya'nın küresel rekabet durumunu ele aldıkları çalışmada zaman serileri analiziyle, 2007-2014 dönemini kapsayan model tahmini yapmıştır. Analizde çıkan sonuca göre yüksek döviz kurlarının Romanya'nın ihracatı üzerinde yeterli olmadığı, Romanya malları üzerinde rekabet şansını yeterli derecede arttırmadığı sonucuna ulaşmıştır.

Bari ve Togba, 2017 yılında Liberya için 1980-2015 yıllarını kapsayan verilerle döviz müdahalesi ve döviz kurlarının dış ticaret dengesi, ihracat ve ithalat üzerindeki etkilerini araştırmıştır. Analiz sonuçlara göre, nominal döviz kuru ihracat üzerinde anlamlı etki yaratırken, reel döviz kuru için bu sonuç bulunamamıştır. Nominal döviz kurları dış ticaret dengesi üzerinde anlamlı fakat ters oranlı bir etkiye sebep olurken, reel döviz kurları dış ticaret dengesi üzerinde pozitif bir etkiye yol açmaktadır. 
Begović ve Kreso, 2017 yılında Türkiye'nin de dahil olduğu Avrupa'nın 17 geçiş ülkesinde reel efektif döviz kurunun 2000-2015 dönemi arasında dış ticaret dengesi üzerindeki etkisini panel veri analizi sabit etkiler yöntemiyle araştırmıştır. Elde edilen analiz sonuçlara göre bu ülkelerin yüksek ithalat bağımlılığı ve düşük ihracat kapasitelerinden dolayı reel efektif döviz kurunun ticaret dengesi üzerinde olumsuz etkilere yol açmakta ve reel kurların değer kaybetmesi ticareti negatif etkilemektedir.

Chaudhary vd., 2016 yılında Güney Asya ve Güney Doğu Asya ülkelerinden oluşan 8 ülkede 1979-2010 yılları arasında kurların dış ticaret üzerindeki etkilerini, ihracat ve ithalat üzerinde ayrı ayrı incelemiştir. Panel veri ile yapılan ARDL testi sonuçlarına göre kurlarla ihracat arasında uzun dönemli bir ilişki çoğu ülkede varken, kurlarla ithalat arasında uzun dönemli bir ilişkinin sadece bir ülkede olduğu ve kısa dönemde döviz kuru ile dış ticaret arasında herhangi bir ilişkisinin olmadığı sonucuna ulaşılmıştır.

Lotfalipour ve Bazargan, 2014 yılında yaptıkları çalışmalarında, İran'da reel döviz kurlarının dış ticaret üzerindeki etkisini panel veri yöntemi GARCH $(1,1)$ yaklaşımıyla araştırmıştır. 1993-2011 dönemini kapsayan çalışmanın sonuçlarına göre reel efektif döviz kurları İran'ın dış ticaret dengesi üzerinde önemli bir etkiye sahip değildir. Ticaret dengesinin ihracattan çok ithalattan etkilendiği ve bu nedenle İran'ın ithal ikameci politikalar uygulaması gerektiği sonucuna ulaşılmıştır.

Kaya, 2014 yılında BRICS ülkeleri üzerine yaptığı çalışmada Rusya'ya ait verilerin sıkıntılı olmasından dolayı Rusya'yı çalışmaya dahil etmemiştir. Geriye kalan 4 ülkeyle yaptığ çalışmada, 1985-2011 dönemine ait verilerle döviz kurları, dış ticaret ve GSYH arasında ilişkiyi incelemiştir. Analiz sonuçlara göre, döviz kurlarının arttığı dönemdeki ihracattaki artışlarla döviz kurlarının azaldığı dönemdeki ihracat artışları arasında önemli bir farkın olmadığı ortaya çıkmıştır. Yani kurların düştüğü yıllarda BRICS ülkelerinde ihracat artmamaktadır.

Kannaiah ve Murty, 2017 yılında, döviz kurlarının ve ticaret açılarının etkisini BRICS ülkeleri için analiz etmiştir. 15 yıllık verilerle zaman serileri ve panel veri yönteminin kullanıldığı analiz sonuçlarına göre dış ticaret açığı arttıkça ülkeye giren yatırımlar artmaktadır. Bu durum karşısında ülkeler ulusal paralarını liberal piyasalarda serbest bırakmaktadır. Bu durum kurların yükselmesine ve böylece ihracatın artmasına, yerli ürünlerin rekabet şansının artmasına ve böylece GSYH'nin artmasına neden olmuştur.

Moodley, 2010 yılında BRIC ülkeleri ve Güney Afrika arasında tarımsal ticaret ve döviz kurlarını ele almış, J eğrisinin geçerli olup olmadığını test etmiştir. Çalışma 1994-2009 arası çeyrek verilerle panel ARDL yöntemiyle tahmin etmiştir. Çalışmada, Güney Afrika para birimi olan Rand'ın devalüasyonunu uzun vadede Güney Afrika ile BRIC ülkeleri arasında bir iyileşmeye yol açmadığ 1 ve J Eğrisinin geçerli olmadığı sonucuna ulaşmıştır.

Maradiaga vd., 2012 yılında yaptıkları çalışmada, 1961-2008 dönemi BRICS ülkelerinde döviz kuru oynaklıklarını incelemiştir. Nedensellik ve VAR analizi yapılan çalışmada Çin ve Brezilya'nın tarım ihracatı üzerinde döviz kurlarının etkili olduğu sonucuna ulaşmıştır. Diğer ülkelerde bir bağlantı çıkmamıştır. Brezilya ve Çin'in yerel paralarının dolar ve Euro karşısında dalgalanması bu iki ülkenin ihracatını olumsuz yönde etkileyebileceği sonucuna ulaşmıştır.

Rasoulinezhad ve Jabalemeli, 2018 yılında BRICS ülkelerinin ticarette partnerleriyle benzer bütünleşme kurup kurmadıklarını analiz etmiştir. 2001-2015 dönemini kapsayan çalışmada zaman serileri analizi ve Panel Gravity yöntemi kullanılmıştır. Sonuçlara göre Çin'in Yuan'ın kur değerindeki değişimler, ticarette diğer BRICS ülkelerine göre daha etkilidir. Çalışmada coğrafi konumun ticaret üzerindeki etkileri de araştırılmıştır. 
Somany ve Shekhar, 2012 yılında döviz kuru oynaklığının özellikle Hindistan'da ticaret ve ihracat üzerindeki etkisini araştırmış ve analiz sonuçlara göre Hint Rupisi'ndeki değer kaybı ihracatı arttırmış gibi gözükse de teorinin iddia ettiği gibi dış ticaret açığının kapatamamıştır. Bu bağlamda, ulusal paranın değer kaybetmesi dış ticaret performansı üzerinde bir etkiye yol açmamıştır. Dış ticareti belirleyen unsur daha çok küresel talepteki değişimlerdir.

Alptekin, 2009 yılında yaptığı çalışmada, Türkiye'de reel döviz kurlarının dış ticaret üzerindeki etkisini araştırmıştır. 1992-2009 dönemi çeyrek verilerle yapılan analizde VAR modeliyle nedensellik, etki tepki analizi ve varyans araştırma testi yapmış ve analizde, reel döviz kurları ile dış ticaret hacminde ve dış ticaret dengesi üzerinde bir etkisi olmadığı sonucuna ulaşmıştır.

Hacıevliyagil ve Demir, 2016 yılında döviz kurları ile makro ekonomik değişkenler arasındaki ilişkiyi BRICS ülkeleri ve Türkiye karşılaştırması yaparak incelemiştir. Analiz sonuçlara göre sadece Türkiye ve Hindistan'da ithalatın kurlar üzerinde bir etkisi yoktur. Fakat Türkiye'de ithalatın ihracattan daha fazla artması kurların yükselmesine, BRICS ülkeleri ile kıyaslandığında Türkiye'nin cari açığının daha olumsuz bir durumda olduğu ortaya çıkmıştır. BRIC ülkelerinde kurlarla ihracat arasında ters yönlü bir ilişki vardır. Ayrıca 2008 küresel krizinde Türkiye, BRICS ülkelerine göre daha fazla olumsuz yönde etkilenmiştir. Bir diğer sonuca göre, ticarette ulusal paranın kullanılması diş ticaret performanslarını arttıracağı sonuçlarına ulaşmıştır.

Chani vd., 2017 yılında yaptıkları çalışmada reel döviz kurlarının Pakistan ve dünyada ihracatı üzerindeki etkisini incelemiş ve analiz sonuçlarına göre, Pakistan' da; reel döviz kurlarının ihracat üzerinde negatif fakat önemsiz bir etkiye sahip olduğu belirtilmiştir.

\section{AMPİIIK ANALİZ}

\section{Veri Seti ve Model}

Bu çalışmada, döviz kurlarının ticari dışa açıklık üzerindeki etkisi BRICS-T ülkeleri için, 19962017 dönemi yıllık veriler kullanılarak analiz edilmiştir. Bağımlı değişken olarak modele alınan ticari dışa açıklık serisi (TO), ihracat ve ithalat toplamının GSYH oranı şeklinde oluşturulmuştur. Bağımsız değişken olarak alınan döviz kuru serisi (EXC), ulusal otoriteler tarafından belirlenen döviz kurunu veya yasal olarak onaylanmış döviz piyasasında belirlenen oranı ifade etmektedir. ABD dolarına göre yerel para birimlerinin kullanıldığı döviz kuru, aylık ortalamalar baz alınarak yıllık veri oluşturulmuştur. Modele kontrol değişken olarak alınan enflasyon serisini (CPI) temsilen alınan tüketici fiyat endeksi, değiştirilebilecek bir mal ve hizmet sepeti edinme maliyetinin ortalama tüketiciye olan yıllık yüzde değişimini göstermektedir. Modelde kullanılan tüm veriler Dünya Bankası (World Development Indicators) sisteminden alınmıştır.

Bu çalışmada, döviz kurlarının ticari dışa açıklık üzerindeki etkisi araştırılmıştır. Bu bağlamda aşağıdaki model tahmin edilmiştir.

$T O_{i t}=\alpha_{0 i}+\alpha_{1 i} E X C_{i t}+\alpha_{2 i} C P I_{i t}+\varepsilon_{i t}$

\section{Yöntem}

Çalışmada öncelikle serilerin durağanlıkları, Augmented Dickey Fuller (ADF) testi ve PhillipsPerron $(P P)$ testi yöntemleriyle incelenmiştir. Birim kök test sonuçlarına göre seriler arasındaki eşbütünleşme ilişkisi, uzun ve kısa dönem analizleri, ARDL-PMG yaklaşımıyla yapılmıştır (Pesaran vd., 1999). Panel ARDL (Autoregressive Distributed Lag) yöntemi, Pesaran, Shin ve Smith (2001) tarafından geliştirilmiştir. Bu yöntemin diğer eşbütünleşme yöntemlerinden en 
önemli farkı bütün serilerin aynı düzeyde durağan olmaları gerekmemektedir. Panel $A R D L$ yönteminin diğer bir avantajı, küçük örneklemlerde de sağlam ve etkin sonuçlar vermesidir (Narayan ve Narayan, 2004).

Ayrıca bu yöntem doğru ve tutarlı tahminciler sunar, çünkü modelin bağımlı ve bağımsız değişkenleri için gecikme uzunluğu ekleyerek modelin sorunları azaltmaktadır (Pesaran vd., 1999). Panel $A R D L(p, q)$ modelindeki uzun dönem değişkenler arasındaki ilişki aşağıdaki gibidir;

$\Delta Y_{1, i t}=\alpha_{1 i}+\gamma_{1 i} Y_{1, i t-1}+\sum_{l=2}^{k} \gamma_{1 i} X_{1, i t-1}+\sum_{j=1}^{p-1} \sigma_{1 i j} \Delta Y_{1, i t-j}+\sum_{j=0}^{q-1} \sum_{l=2}^{k} \sigma_{1 i j} \Delta X_{1, i t-j}+\mu_{1, i t}$

Burada, $Y_{1}$; bağımlı değişken ve $X_{1}$; bağımsız değişken, $l$; değişken sayısı $(l=1,2,3$.$) , \mu_{\mathrm{it}}$; hata terimi ve $\Delta$; birinci derece fark operatörüdür. Bu bağlamda oluşturulan modelimiz aşağıdaki gibidir;

$\Delta \mathrm{TO}_{i t}=\alpha_{1 i}+\gamma_{1 i} \mathrm{TO}_{i t-1}+\gamma_{2 i} \mathrm{EXC}_{i t-1}+\gamma_{3 i} C P I_{i t-1}+\sum_{j=1}^{p} \sigma_{1 i} \Delta \mathrm{TO}_{i t-j}+\sum_{i=0}^{q} \sigma_{2 i} \Delta E X C_{i t-j}+\sum_{i=0}^{q} \sigma_{3 i} \Delta C P I_{i t-j}+\mu 1_{1 i t}$

Gecikme uzunluğu seçilirken $A I C$ bilgi kriteri (Akaike Information Criterian) ve $S B C$ bilgi kriteri (Schwarz Bayessian Criterion) seçilmiştir.

Değişkenler arasındaki geleneksel eşbütünleşme ilişkisini test eden Pedroni (1995, 1999, 2004); Kao (1999) ve Bai ve Ng (2001) gibi çalışmalarda tüm değişkenlerin I(1) olması gerekmektedir. Ancak Panel $A R D L$ yönteminde olası uzun vadeli ilişkilerin varlığını aşağıdaki alternatif hipotezlere göre test etme imkânı sunar. Panel ARDL eşbütünleşme hipotezi aşağıdaki gibidir.

$\left(H_{0}: \gamma_{1 i}=\gamma_{2 i}=\gamma_{3 i}=0\right)$

$\left(H_{1:} \gamma_{1 i} \neq \gamma_{2 i} \neq \gamma_{3 i} \neq 0\right)$

4 nolu denkleme göre boş hipotez eşbütünleşme ilişkisi yoktur ve alternatif hipotez olan 5 nolu denklemde eşbütünleşme ilişkisi vardır.

Sınır testi prosedürü Fisher istatistiklerine (F-istatistik) veya Wald istatistiklerine dayanır. Pesaran vd. (2001) belirli bir kritik değeri göz önünde bulundurmuşlardır. Birincisi, Panel ARDL modelinde yer alan tüm değişkenlerin $I(0)$ olduğunu, diğer değişkenlerin I(1) olduğunu varsayar. Hesaplanan değer eğer F-istatistiği üst kritik değerinden büyükse, $H_{0}$ reddedilir. Eğer hesaplanan değer iki kritik değer arasında ise eşbütünleşme sonuçsuz kalır ve son olarak eğer hesaplanan değer F-istatistiği alt değerinden küçükse $H_{0}$ reddedilemez.

İkinci adımda, eğer eşbütünleşme ilişkisi kurulursa, uzun dönem denklem tahmin edilebilir.

Üçüncü adımda, bir hata düzeltme modeli (ECM) tahmin edilerek kısa vadeli dinamik ilişki elde edilir. $E C M$ aşağıdaki gibi tanımlanmıştır:

$\Delta Y_{1, i t}=\alpha_{1 i}+\sum_{j=1}^{p-1} \beta_{1 i j} \Delta Y_{1, i t-j}+\sum_{j=0}^{q-1} \sum_{l=2}^{k} \beta_{l i j} \Delta X_{1, i t-j}+\eta_{l i} E C T_{1, i t-1}+\mu_{l i t}$

Burada kalıntıların $\mu_{\text {lit }}(1=\{1,2,3\}$,$) bağımsız olduğu ve normalde sıfır ortalama ve sabit varyans$ ile dağılmış ve $E C T_{l, i t-1}(1=\{1,2,3\})$ tanımlanan hata düzeltme terimidir. $\eta_{l i}$ parametresi ise denge seviyesinin ayarlama hızını gösterir.

Ayrıca, TO bağımlı değişken ise, ECM modeli aşağıdaki gibidir:

$\Delta \mathrm{TO}_{i t}=\alpha_{1 i}+\sum_{j=1}^{p-1} \beta_{1 i j} \Delta \mathrm{TO}_{i t-j}+\sum_{j=0}^{q-1} \beta_{2 i j} \Delta E X C_{i t-j}+\sum_{j=0}^{q-1} \beta_{3 i j} \Delta C P I_{i t-j}+\eta_{1 i} E C T_{1, i t-1}+\mu_{1 i t}$

Panel ARDL modelinin tahmincileri ve tüm parametreler PMG (Pooled Mean Group) metodu kullanılarak elde edilir. Maksimum olasılık yöntemine dayanan bu tahmin prosedürü en tutarlı olarak kabul edilir çünkü bireysel özellikleri (ülke, bölge vb.) hesaba katar ve uzun süreli ilişkilerin üstün bir değerlendirmesini sağlar. Bu nedenle elde edilen PMG tahmincileri, belirtildiği gibi asimptotik ve normal olarak dağıtılmıştır (Pesaran vd., 1999). 


\section{Panel Birim Kök Testi}

Panel veri analizi yaparken öncelikle modele alınan serilerin durağan olması gerekmektedir. Çünkü durağan olmayan serilerle yapılan tahminler sapmalı olabilmektedir (Gujarati, 1999: 712). Verilerin durağanlığını test etmek için çeşitli paneller birim kök testleri kullanılmaktadır. Çalışmamızda serilerin durağanlık dereceleri $A D F$ ve $P P$ testleriyle araştııılmış ve birim kök testileri yapılmıştır.

DF testi, yalın, sabit terimli ve sabit terimli trendli olmak üzere üç denklem şeklinde yazılmaktadır (Dickey ve Fuller, 1979);

Yalın hali:

Sabit terimli:

Sabit terimli ve trendli:

Yapılan test sonuçları $D F$ istatistikleri ile karşılaştırılarak; sıfır hipotezi (H0: $\gamma=0)$, alternatif hipoteze karşı (H1: $\gamma \neq 0$ ) test edilmektedir. Burada ilk hipotez seride birim kökün varlı̆̆ını alternatif hipotez ise serinin durağan olduğunu yani seride birim kök olmadığını ifade etmektedir. Ancak hata teriminde içsel bağıntı sorunun olması durumunda Denklem 10 yeniden düzenlenir:

$$
\Delta Y=\alpha_{0}+\alpha_{1} t+\gamma Y_{t-1}+\beta i \sum_{i=1}^{m} \Delta Y_{t-i}+\mu t
$$

Denklem 11'de m gecikme uzunluğunu, $\Delta$ fark operatörünü ifade etmektedir. Bu denklemde ifade edildiği gibi yapılan test $A D F$ testidir.

$A D F$ testinin $D F$ testinden bir üstünlüğü modele gecikmeli değerler eklenerek otokorelasyon sorunu ortadan kaldırmasıdır. Phillips-Perron (1988) birim kök testi ise $A D F$ birim kök testini doğrulama amaciyla kontrol birim kök testi olarak analiz edilmiştir. $A D F$ ve $P P$ testi ile elde edilen sonuçlar Tablo 1'de görülmektedir.

Tablo 1: Panel Birim Kök Test Sonuçları

\begin{tabular}{|c|c|c|c|c|c|c|c|c|}
\hline \multirow[b]{3}{*}{$\begin{array}{c}\text { Değişkenle } \\
\mathrm{r}\end{array}$} & \multicolumn{4}{|c|}{ ADF Testi } & \multicolumn{4}{|c|}{ PP Testi } \\
\hline & \multicolumn{2}{|c|}{ Sabit } & \multicolumn{2}{|c|}{ Sabit + Trend } & \multicolumn{2}{|c|}{ Sabit } & \multicolumn{2}{|c|}{ Sabit + Trend } \\
\hline & $\begin{array}{c}\mathrm{t} \\
\text { istatistiğ } \\
\mathrm{i}\end{array}$ & $\begin{array}{c}\text { Olasılık } \\
\text { Değeri }\end{array}$ & $\begin{array}{c}\mathrm{t} \\
\text { istatistiğ } \\
\mathrm{i}\end{array}$ & $\begin{array}{c}\text { Olasılık } \\
\text { Değeri }\end{array}$ & $\begin{array}{c}\mathrm{t} \\
\text { istatisti } \breve{g} \\
\mathrm{i}\end{array}$ & $\begin{array}{l}\text { Olasıllk } \\
\text { Değeri }\end{array}$ & $\begin{array}{c}\mathrm{t} \\
\text { istatistiğ } \\
\mathrm{i}\end{array}$ & $\begin{array}{l}\text { Olasilık } \\
\text { Değeri }\end{array}$ \\
\hline $\mathrm{TO}$ & 22.49 & 0.03 & 40.30 & 0.00 & 16.77 & 0.15 & 24.67 & 0.01 \\
\hline EXC & 9.03 & 0.70 & 15.91 & 0.19 & 3.30 & 0.99 & 2.65 & 0.99 \\
\hline CPI & 38.58 & 0.00 & 25.85 & 0.01 & 41.78 & 0.00 & 31.29 & 0.00 \\
\hline$\Delta \mathrm{TO}$ & 59.32 & 0.00 & 49.24 & 0.00 & 69.38 & 0.00 & 62.96 & 0.00 \\
\hline$\Delta \mathrm{EXC}$ & 33.56 & 0.00 & 19.87 & 0.06 & 29.40 & 0.00 & 16.29 & 0.17 \\
\hline$\triangle \mathrm{CPI}$ & 93.20 & 0.00 & 51.75 & 0.00 & 275.78 & 0.00 & 122.59 & 0.00 \\
\hline
\end{tabular}

Not: Panel birim kök testi analizinde optimum gecikme uzunluğu belirlenirken Akaike bilgi kriter baz alınmış ve band genişliği belirlemede ise, Newey-West kriteri kullanılmıştır.

Tablo 1'deki birim kök test sonuçları incelendiğinde $T O$ ve CPI serileri düzey değerinde durağan olduğu $I(0)$ ve $E X C$ serisi birinci farkı alındıktan sonra durağan hale geldiği I(1) görülmüştür. 


\section{Panel Nedensellik Testi}

Bu çalışmada, seriler arasındaki nedensellik ilişkisinin varlığı Dumitrescu ve Hurlin (2012) tarafından geliştirilen Dumitrescu ve Hurlin Panel Nedensellik Testi yöntemiyle incelenmiştir. Bu testin diğer nedensellik testlerinden ayıran başlıca avantajlar; panel veri analizinde yatay kesit bağımlılığını göz önünde tutması, zaman boyutu $(T)$ ve yatay kesit boyutu $(N)$ büyüklüğünü göz önünde bulundurmaması ( $T>N$ veya $N>T$ geçerli olması), dengesiz panel veri analizinde de etkin sonuçlar vermesidir (Dumitrescu ve Hurlin, 2012: 1457). Doğrusal bir model kullanarak elde edilen nedensellik testi aşağıdaki şekilde ifade edilmektedir:

$Y_{i, t}=\alpha_{i}+\sum_{k=1}^{K} \gamma_{i}^{k} Y_{i,--k}+\sum_{k=1}^{K} \beta_{i}^{k} X_{i,--k}+\varepsilon_{i, t}$

Burada; $K$ optimum gecikme uzunluğunu ve $\varepsilon_{i, t}$ hata terimini ifade etmektedir. Bu nedensellik yönteminin önemli iki kısıtı bulunmaktadır. Birincisi serilerin durağan olduğu durumlarda geçerlidir. İkinci olarak da denklemdeki katsayıların homojen olduğu varsayımı geçerlidir. Bu testin hipotezleri aşağıdaki gibidir;

$H_{0}: \beta_{i}^{(k)}=0 \forall i=1 ; . . N$ nedensellik ilişkisi yoktur;

$H_{1}: \beta_{i}=0 \quad \forall i=1 ; . ., N_{1}$

$\beta_{i} \neq 0 \quad \forall i=N_{1}+1, N_{1}+2, . ., N$ nedensellik ilişkisi vardır.

Dumitrescu ve Hurlin (2012), bu hipotezleri sinamak üzere her bir yatay kesit için bireysel Wald istatistiklerinin $W_{i, T}$ değerlerini hesaplamakta ve sonra bu değerlerin aritmetik ortalamasını alarak panele ait Wald istatistik değerine $\left(W_{N, T}^{H N C}\right)$ ulaşmaktadır.

Monte-Carlo simülasyonunu kullanarak test istatistiklerini hesaplayan Demitrescu ve Hurlin (2012), $T>N$ olduğunda asimptotik dağılıma sahip $\mathrm{W}_{\mathrm{N}, \mathrm{T}}^{\mathrm{HNC}}$ test istatistiğini kullanmaktadır. Bu test istatistiği;

$Z_{N, T}^{H N C}=\sqrt{\frac{N}{2 K}}\left(W_{N, T}^{H N C}-K\right)$

şeklindedir. Durağan hale getirilmiş serilerle yapılan Dumitrescu ve Hurlin (2012) panel nedensellik testi sonuçları Tablo 2' de verilmiştir.

Tablo 2: Dumitrescu ve Hurlin (2012) Panel Nedensellik Test Sonuçları

\begin{tabular}{|c|c|c|c|}
\hline $\begin{array}{l}\text { Nedensellik } \\
\text { Yönü }\end{array}$ & Wist & $\begin{array}{l}\text { Olasılık } \\
\text { Değeri }\end{array}$ & Karar \\
\hline $\mathrm{EXC} \longrightarrow \mathrm{TO}$ & 9.20 & 0.00 & \multirow{2}{*}{$\begin{array}{l}\text { Döviz kurundan ticari açıklığa doğru tek yönlü bir } \\
\text { nedensellik ilişkisi vardır. }\end{array}$} \\
\hline $\mathrm{TO} \longrightarrow \mathrm{EXC}$ & 2.75 & 0.58 & \\
\hline $\mathrm{CPI} \longrightarrow \mathrm{TO}$ & 6.13 & 0.09 & \multirow{2}{*}{$\begin{array}{l}\text { Enflasyondan ticari açıklığa doğru çift yönlü bir } \\
\text { nedensellik iliş̧kisi vardır. }\end{array}$} \\
\hline $\mathrm{TO} \longrightarrow \mathrm{CPI}$ & 11.23 & 0.06 & \\
\hline $\mathrm{CPI} \longrightarrow \mathrm{EXC}$ & 5.71 & 0.16 & \multirow{2}{*}{$\begin{array}{l}\text { Döviz kurundan enflasyona doğru tek yönlü bir } \\
\text { nedensellik ilişkisi vardır. }\end{array}$} \\
\hline $\mathrm{EXC} \longrightarrow \mathrm{CPI}$ & 9.18 & 0.00 & \\
\hline
\end{tabular}

Not: Panel nedensellik analizinde Lag uzunluğu 3 olarak alınmıştır.

Tablo 2'de, Dumitrescu ve Hurlin (2012) Panel Nedensellik Test Sonuçlarına göre, döviz kurundan ticari açıllğa doğru ve döviz kurundan enflasyona doğru tek yönlü bir nedensellik 
ilişkisi varken, enflasyondan ticari açıklığa doğru çift yönlü bir nedensellik ilişkisi tespit edilmiştir.

\section{Panel Eşbütünleşme Testi}

Panel birim kök testi sonucunda seriler farklı düzeylerde durağan oldukları için Panel ARDL yöntemi kullanılacaktır. Bu bağlamda, Panel ARDL modelinin bu çalışmaya uyarlanmış biçimi Denklem 16'da gösterilmiştir;

$\Delta \mathrm{TO}_{t}=\beta_{0}+\sum_{i=1}^{m} \beta_{1 i} \Delta \mathrm{TO}_{t-i}+\sum_{i=0}^{m} \beta_{2 i} \Delta E X C_{t-i}+\sum_{i=0}^{m} \beta_{3 i} \Delta C P I_{t-i}+\beta_{4} \mathrm{TO}_{t-1}+\beta_{5} E X C_{t-1}+\beta_{6} C P I_{t-1}+\varepsilon_{1 t}$

Denklem $16^{\prime}$ daki modelde $\mathrm{m}$ optimum gecikme uzunluğunu, $\Delta$ fark operatörünü ve $\varepsilon_{t}$ hata terimini göstermektedir.

\section{Kısa ve Uzun Dönem Analizi}

Uzun ve kısa dönem analizini tahmin ederken Panel ARDL yöntemi PMG yaklaşımı kullanılmıştır. Panel ARDL yönteminde uzun dönem denkleminin çalışmamıza uyarlanmış biçimi Denklem 17 'de gösterilmiştir;

$$
\mathrm{TO}_{t}=\beta_{0}+\sum_{i=1}^{m} \beta_{1 i} \mathrm{TO}_{t-i}+\sum_{i=0}^{n} \beta_{2 i} E X C_{t-i}+\sum_{i=0}^{p} \beta_{3 i} C P I_{t-i}+\varepsilon t
$$

Denklem 17'de, gecikme uzunlukları m, n ve p olup, bu gecikme uzunlukları AIC bilge kriteri baz alınarak hesaplanmıştır. Bu bağlamda, yapılan analiz Kamas ve Joyce'nin 1993 yılındaki çalışmasıyla uyumludur. Analizde, bağımlı değişkenin bir gecikmeli değeri bağımsız değişken olarak alınmış ve buna göre regresyon hesaplanmıştır. Regresyon hesaplanırken içsel bağıntısız modelin gecikme değeri, en küçük AIC değeri baz alınarak bulunmuştur. Daha sonra bağımsız değişkenin gecikme sayısı belirlenirken yine en küçük AIC değeri baz alınır ve bağımlı değişkenin belirlenen gecikme uzunluğu sabit kabul edilir. Bu yapılan işlemler diğer bağımsız değişkenler için de tekrarlanarak optimum gecikme uzunlukları belirlenir. Optimum gecikme uzunluğu tüm değişkenler için hesaplanmış ve ARDL $(2,4,4)$ modeli elde edilmiştir. Kisa ve uzun dönem ARDL $(2,4,4)$ modelinin tahmin sonuçları Tablo 3' sunulmuştur.

Tablo 3: Uzun Dönem PMG ve ECM Tahmin Sonuçları

\begin{tabular}{|c|c|c|c|}
\hline \multicolumn{5}{|c|}{ Uzun Dönem } \\
\hline Değişkenler & Katsayı & t-istatistik & Olasılık Değeri \\
\hline EXC & 0.24 & 0.83 & 0.40 \\
\hline CPI & 1.26 & 6.98 & 0.00 \\
\hline \multicolumn{4}{|c|}{ Kisa Dönem } \\
\hline$\Delta$ EXC & -4.41 & -0.48 & 0.62 \\
\hline$\Delta$ CPI & 0.01 & 0.03 & 0.97 \\
\hline ECT & -0.43 & -2.85 & 0.00 \\
\hline C & 13.16 & 7.28 & 0.00 \\
\hline
\end{tabular}

Tablo 3'te uzun dönem analizine bakıldığında, döviz kuru serisinin ticari dışa açıklık serisi üzerindeki ilişkisi anlamlı çıkmamıştır. Ancak enflasyon serininin ticari dışa açıklık serisiyle pozitif bir ilişki içinde olup; enflasyondaki \%1'lik artışın ticari açıklığı $\% 1,26$ oranında arttırdığ analiz edilmiştir. 
Tablo 3'te kısa dönem analizine bakıldığında ise, ECT (hata düzeltme terimi) katsayısı negatif ve istatistiksel olarak anlamlıdır. Kısa dönemde ECT katsayısının negatif çıkması, serilerde çıkan sapmaların uzun dönemde dengeye yakınsayacağı anlamına gelmektedir.

Tablo 4: BRICS-T Ülkeleri için Yatay Kesit Bağımlılığı Hata Terimi Sonuçları

\begin{tabular}{|l|c|c|c|}
\hline \multirow{2}{*}{\multicolumn{1}{c|}{ Ülkeler }} & \multicolumn{3}{|c|}{ Hata Terimi (ECT) } \\
\cline { 2 - 4 } & Katsayı & t-istatistik & Olasıllk Değeri \\
\hline Brezilya & -1.177 & -14.408 & 0.000 \\
\hline Rusya & -0.269 & -12.913 & 0.001 \\
\hline Hindistan & -0.273 & -24.499 & 0.001 \\
\hline Çin & -0.470 & -10.307 & 0.000 \\
\hline Güney Afrika & -0.159 & -33.617 & 0.000 \\
\hline Türkiye & -0.279 & -18.075 & 0.000 \\
\hline
\end{tabular}

Tablo 4'te tüm BRICS-T ülkelerinin ECT katsayıları negatif ve istatistiksel olarak anlamlı çıkmıştır. BRICS-T ülkelerinde, kısa dönemde çıkan sapmaların hepsi uzun dönemde denge değerine yakınsayacaktır. Ancak Brezilya'nın bu yakınsama durumu diğer ülkelere göre biraz daha geç olmaktadır.

\section{SONUÇ}

Bu çalışmada, döviz kurlarının ticari dışa açıklık üzerindeki etkisi, gelişmekte olan ve yükselen ekonomiler olarak anılan BRICS ülkelerine Türkiye'de (T) BRICS-T grubu oluşturulmuştur. BRICS-T ülkelerine ait 1996-2017 dönemi yıllık veriler kullanılarak panel nedensellik ve panel eşbütünleşme yöntemleri tahmin edilmiştir. Serilerin durağanlığı; ADF ve PP panel birim kök testi ile incelenmiş olup, TO ve CPI serileri düzey değerinde durağan olduğu $I(0)$ ve EXC serisi birinci farkı alındıktan sonra durağan hale geldiği I(1) görülmüştür. Serilerin farklı düzeylerde durağan çıkmasından dolayı eşbütünleşme ilişkisi panel ARDL yöntemiyle analiz edilmiştir. Seriler arasındaki nedensellik ilişkisi ise Dumitrescu ve Hurlin (2012) tarafından geliştirilen panel nedensellik yöntemiyle incelenmiştir. Analiz sonucunda, döviz kurundan ticari açıklığa doğru ve döviz kurundan enflasyona doğru tek yönlü bir nedensellik ilişkisi varken, enflasyondan ticari açıklığa doğru çift yönlü bir nedensellik ilişkisi tespit edilmiştir.

Seriler arasındaki eşbütünleşme ilişkisinin varlığı, uzun ve kısa dönem için panel ARDL-PMG yaklaşımıyla tahmin edilmiştir. Uzun dönem analizine bakıldığında, döviz kuru serisinin ticari dışa açıklık serisi üzerindeki ilişkisi anlamlı çıkmamıştır. Ancak enflasyon serininin ticari dişa açılık serisiyle pozitif bir ilişki içinde olup; enflasyondaki \%1'lik artışın ticari açıklığ1 \%1,26 oranında arttırdığı analiz edilmiştir. Kısa dönem analizine bakıldığında ise, hata düzeltme teriminin katsayısının (ECT) negatif ve istatistiksel olarak anlamlı olduğu da görülmüştür. Bu durum, uzun dönemde birlikte hareket eden seriler arasında, kısa dönemde meydana gelen sapmaların ortadan kalktığı ve serilerin tekrar uzun dönem denge değerine yakınsadıkları anlamina gelmektedir.

$\mathrm{Bu}$ çalışmada elde edilen bulgulara dayanarak gelişmekte olan BRICS-T ülkelerinde; ticari dişa açıklığa enflasyonun neden olduğu görülmektedir. BRICS-T ülkelerinde enflasyon ile ticari dışa açıklık arasındaki ilişkinin niteliği her ülkenin kendine has yapısal bazı unsurlarına dayansa da genel olarak enflasyondaki artışlar ticari dışa açılığı arttırmaktadır. Bu durum BRICS-T 
ülkelerinde yatırım amaçlı sermaye girişlerinde bir azalmaya ve ekonomik kırılganlığı attırma yönünde bir etki yapabilir.

Yükselen ekonomilerin ara girdi ve yüksek teknolojili ürünlerde dışa bağımlılı̆̆ı ve döviz ihtiyacı nedeniyle bu ülkeler döviz kuru-enflasyon-faiz üçlüsü sorunu ile karşı karşıya kalmaktadırlar. Kurların dengede tutulması amacıyla faiz oranları ve ihracat önemli iki kalem olmasına karşın Türkiye gibi ihracatı yeterli olmayan ülkelerde yüksek faiz ve düşük yatırım sorunu ortaya çıkmaktadır. Kurların yüksekliği, Çin gibi ihracatı fazla olan ülkelerde bir fırsat olmasına karşın Türkiye, Hindistan ve Brezilya gibi cari açık veren ülkelerde önemli bir maliyet unsuru olmaktadır. İç piyasada fiyatların dengelenmesi amacıyla ithalat bir yandan dış açıkları artırırken diğer yandan kur talebini arttırmaktadır. Kurlar yükselirken ulusal paranın değer kaybetmesi enflasyonu hızlandırmaktadır. Türkiye'nin 2018 yılında yaşamış olduğu kur krizi enflasyon patlamasına neden oldu. Sonuç olarak, ABD'nin zaman zaman başlattığ da eklendiğinde yükselen ekonomilerin serbest ticaretten beklenen kadar yararlanamadığı görülmektedir. Küresel ekonomik liderlerin yer değiştirmesi, yükselen ekonomilerin sahip oldukları büyük avantajlar küresel politikaların değiştiğini de göstermektedir.

\section{KAYNAKÇA}

Alptekin, V. (2009). Türkiye'de Dış Ticaret-Reel Döviz Kuru İlişkisi: Vektör Otoregresyon (Var) Analizi Yardımıyla Sınanması, Niğde Üniversitesi İktisadi ve İdari Bilimler Fakültesi Dergisi, 2(2): 132149.

Bai, J., and Ng, S. (2001). A Consistent Test for Conditional Symmetry in Time Series Models, Journal of Econometrics, 103(1-2): 225-258.

Bari, B. and Togba, E. D. (2017). The Effect of Foreign Exchange and Real Exchange Rate on Foreign Tradein Liberia: An Application of Autoregressive Distributed Lag (ARDL) Approach. Econ World 2017 Paris Proceedings, 1-23.

Begović, S. and Kreso, S. (2017). The Adverse Effect of Real Effective Exchange Rate Change on Trade Balance in European Transition Countries, Zbornik Radova Ekonomskog Fakulteta u Rijeci: Časopis za Ekonomsku Teoriju i Praksu, 35(2): 277-299.

Bergevin, C.C. (2018). Global Economy in The Decades to Come (India and China Could be The Two Biggest Economic Powers by the Next 20 Years). Desjardins- Economic Studies. https://www.desjardins.com/ressources/pdf/pv181101-e.pdf?resVer=1541090395000 [Erişim Tarihi: 01.07.2019].

Bostan, I., Todareşçu, C. and Firtescu, B. (2018). Exchange Rate Effects on International Commercial Trade Competitiveness, Journal of Riska and Financial Management, 11(19): 1-11.

Chani, M., Qasim, M. and Ahmed, K. (2017). Impact of Exchange Rate on Export in Case of Pakistan, Bulletin of Business and Economics, 6(2): 98-102.

Chaudhary, G., Hashmi, S. and Khan, M. (2016). Exchange Rate and Foreign Trade: A Comparative Study of Major South Asian and South-East Asian Countries, Procedia-Social and Behavioral Sciences, 30: 85-93.

Çetinkaya, M., Uysal, Y. ve Balaylar, N. (2018). Küresel Ticarette Yeniden Korumacılık: Ticaret Savaşlarının Dünya ve Türkiye Ekonomisine Etkileri, Birinci Uluslararası Sosyal Bilimlerde Kritik Araştırmalar Kongresi, 5-7 Ekim 2018. İzmir. ss: 708-720. 
Dickey, D.A. and Fuller, W.A. (1979). Distribution of the Estimators for Autoregressive Time Series with a Unit Root, Journal of the American Statistical Association, 74(366a): 427-431.

Dumitrescu, E.I. and Hurlin, C. (2012). Testing for Granger Non-Causality in Heterogeneous Panels, Economic Modelling, 29(4): 1450-1460.

European Parliament Directorate - General for External Policies-Policy Department (2012). The Role of BRICS in Developing World.

https://www.ecologic.eu/sites/files/project/2013/knoblauch_12_lot5_24_brics.pdf [Erişim Tarihi: 10.08.2019].

Gujarati, D. N. (1999). Temel Ekonometri. (Çeviren, Şenesen, Ü. ve Günlük, Ü.), 7. Basım, Eylül 2010, İstanbul: Literatür Yayıncllk.

Hacievliyagil, N., ve Demir, Y. (2016). Döviz Kurunun Temel Makro Ekonomik Değişkenlerle İlişkisi: Türkiye ve BRICS Ülkeleri Karşılaştırması, Finans Politik \& Ekonomik Yorumlar, 53(615): 41.

Islamic Development Bank, Data Indicator (2018). http://data.isdb.org/pxfdrcg/world-bankdevelopment-indicators-wdi-2017-idb-aggregates?action=download [Erişim Tarihi: 01.04.2019].

Kamas, L., and Joyce, J. P. (1993). Money, Income and Prices Under Fixed Exchange Rates: Evidence from Causality Tests and Vars, Journal of Macroeconomics, 15(4): 747-768.

Kannaiah, D. and Murty, N. (2017). Exchange Rate Intervention and Trade Openness on The Global Economy with Reference to Brazil, Russia, India, China and South Africa (BRICS) Countries, Investment Management and Financial Innovations, 14(3): 339-352.

Kao, C. (1999). Spurious Regression and Residual-Based Tests for Cointegration in Panel Data. Journal of Econometrics, 90(1): 1-44.

Kaya, H. (2014). The Effect of Exchange Rates on BRICS Countries' Exports and GDP, International Journal of Business and Social Science, 5(13): 19-29.

Kharrobi, E. (2011). The Trade Balance and the Real Exchange Rate. Bank of International Settlements BIS Quarterly Review.

Kokotović, F. and Kurečić, P. (2016). The MINT Countries: A regression Analysis of the Selected Economicic Features, International Journal of Management Science and Business Administration, 2(5): 21-23.

Lemco, J. (2016). Are Emerging Markets Still Built on the BRICS?. Vanguard CommentaryResearch. https://personal.vanguard.com/pdf/ISGBRIC.pdf [Erişim Tarihi: 10.08.2019].

Lotfalipour, M. and Bazargan, M. (2014). The Impact of Exchange Rate Volatility on Trade Balance of Iran, Advances in Economics and Business, 2(8): 293-302.

Luna, V.M.I. (2016). BRICS' Bank: Possibilities and Constraints, Economía Informa, 398: 3-22.

Maradiaga, D., Zapata, H. and Pujula, A. (2012). Exchange Volatility in BRICS Countries. Southern Agricultural Economics Association Annual Meeting, Birmingham, AL, February 4-7, 2012.

Moodley, S. (2010). An Estimation of The J Curve Effect between South Africa and The BRIC Countries. Gordon Institute of Business Science, University of Pretoria, Master Thesis, South Africa.

Narayan, P. K., and Narayan, S. (2005). Estimating Income and Price Elasticities of Imports for Fiji in a Cointegration Framework, Economic Modelling, 22(3): 423-438. 
O’Neill, J. (2001). Building Better Global Economic BRICs, Goldmansachs Global Economics Paper, 66:1-15. https://www.goldmansachs.com/insights/archive/archive-pdfs/build-better-brics.pdf [Erişim Tarihi: 10.08.2019].

Onyekwena, C., Taiwo, O., and Uneze, E. (2014). South Africa in BRICS: A Bilateral Trade Analysis, Occasional Paper, 181: 1-31.

Pedroni P. (1995). Panel Cointegration: Asymptotic and Finite Sample Properties of Pooled Time Series Tests, With an Application to the PPP Hypothesis. Working Paper no.95-013, Indiana University.

Pedroni, P. (1999). Critical Values for Cointegration Tests in Heterogeneous Panels with Multiple Regressors. Oxf Bull Econ Stat 61: 653-670.

Pedroni P. (2004). Panel Cointegration: Asymptotic and Finite Sample Properties of Pooled Time Series Tests with an Application to the PPP Hypothesis, Econometric Theory, 20(3): 597-625.

Pesaran, M. H., Shin, Y., and Smith, R. P. (1999). Pooled Mean Group Estimation of Dynamic Heterogeneous Panels, Journal of the American Statistical Association, 94(446): 621-634.

Pesaran, M. H., Shin, Y., and Smith, R. J. (2001). Bounds Testing Approaches to the Analysis of Level Relationships, Journal of Applied Econometrics, 16(3): 289-326.

Phillips, P.C. and Perron, P. (1988). Testing for a Unit Root in Time Series Regression. Biometrika, 75(2): 335-346.

Rasoulinezhad, E. and Jabalameli, F. (2018). Do BRICS Countries have Similar Trade Integration Patterns?, Journal of Economic Integration, 33(01): 1011-1045.

Rodionova, I., and Epifantseva, A. (2017). Positions of the BRICS Countries in World Economics Innovation, Studia Ekonomiczne, 323: 107-117.

Shaygani, B., Hastiani, A.A., Ghaffari,F., Sadeghi, M. and Fadaee, M. (2015). Effects of Exchange Rate Arrangements on Trade Cooperation in BRICS Countries, Asian Economic and Financial Review, 5(3): 563-578.

Somany, S. and Shekhar, S. (2012). Emerging Trends in Exchange Rate Volatility, Trade Performances and Exporter's Profitability. PHD Research Bureua- PHD Chamber of Commerce and Industry. http://www.phdcci.in/wp-content/uploads/2018/11/Emerging-trends-in-exchangerate.pdf_[Erişim Tarihi: 01.07.2019].

Türkiye Cumhuriyet Merkez Bankası, EVDS, (2019).

https://evds2.tcmb.gov.tr/index.php?/evds/serieMarket [Erişim Tarihi: 30.05.2019].

Türkiye İstatistik Kurumu, (2019). http://www.tuik.gov.tr/Start.do [Erişim Tarihi: 30.05.2019].

Trading Economics Indicators, (2019). https://tradingeconomics.com/indicators [Erişim Tarihi: 30.05.2019].

World Bank Data Indicators, (2019). https://data.worldbank.org/topic/trade [Erişim Tarihi: 01.05.2019].

Yamoussoukro Consensus (2008). Yamoussoukro Consensus on South-South Cooperation, Twelfth Session of the Intergovernmental Follow-up and Coordination Committee on Economic Cooperation among Developing Countries Yamoussoukro, Côte d'Ivoire, 10-13 June 2008. URL: http://www.g77.org/ifcc12/Yamoussoukro_Consensus.pdf [Erişim Tarihi: 01.07.2019]. 
Yücesan, M., Torun, M. ve Kurt, S. (2017). Döviz Kuru Değişimlerinin Dış Ticaret Üzerine Etkileri: Türkiye'nin Yeni Dış Ticaret Pazarları Arayışında Seçilmiş Ülke Grupları Üzerine Ekonometrik Bir Analiz, Journal of International Social Research, 10(52): 1288-1297. 